\title{
Professor Wadia's contributions to neurology and spinocerebellar ataxia type 2
}

\author{
A contribuição do professor Wadia à neurologia e a ataxia espinocerebelar tipo 2 \\ Fernando Spina Tensini', José Luiz Pedroso², Orlando G.P. Barsottini², Hélio A. G. Teive ${ }^{1}$
}

\begin{abstract}
The authors present a historical review of the seminal contributions of Professor N. H. Wadia (1925-2016) to neurology, in particular, the first description of spinocerebellar ataxia type 2.
\end{abstract}

Keywords: spinocerebellar ataxias; saccades.

RESUMO

Os autores apresentam uma revisão histórica sobre a contribuição seminal do Professor N.H. Wadia para a Neurologia, em particular, a primeira descrição mundial da ataxia espinocerebelar tipo 2.

Palavras-chave: ataxias espinocerebelares; movimentos sacádicos.

Spinocerebellar ataxia type 2 (SCA 2 ) is a rare hereditary neurodegenerative disease caused by expansion of an unstable repeat in the ataxin-2 gene on chromosome 12 (12q23-24.1)1. Clinically, SCA 2 is characterized by progressive cerebellar ataxia accompanied by slow saccadic eye movements and signs of peripheral neuropathy ${ }^{1}$. However, the phenotype can be pleomorphic and can include parkinsonism (L-dopa responsive), dementia, movement disorders (chorea and dystonia), amyotrophic lateral sclerosis (ALS) and other extracerebellar features ${ }^{1,2}$. Spinocerebellar ataxia type 2 has a worldwide distribution but is most frequently found in Cuba (in the province of Holguin) $)^{1,3}$. In 1989, Orozco et al. published an outstanding paper on SCA 2 in which they described its clinical, neuropathological and biochemical features ${ }^{3}$. However, this disorder had already been described in detail in India in 1971 by Wadia and Swami, who emphasized the presence of cerebellar ataxia, and slow eye movements in particular ${ }^{4}$. Here, we review this very important contribution by Prof. Wadia, of the first clinical description of SCA 2.

\section{NOSHIR H. WADIA - A SHORT BIOGRAPHY}

Noshir Hormusji Wadia (Figure 1) was born in 1925 in Surat, Gujarat, India. He chose medicine as his vocation and graduated from Grant Medical College, Mumbai, India, in $1950^{5}$. He then went to London, where he trained as a neurologist between 1952 and 1956. In 1957, he returned to India to dedicate his life to neurology, becoming a clinical neurologist of renowned expertise, an eminent professor and a highly-qualified researcher ${ }^{5}$. In recognition of his contributions to medicine, and neurology in particular, he was awarded the Certificate of Appreciation for Services to Neurology by the World Federation of Neurology in 1993, the Padma Brushan by the Indian government in 2012, honorary membership

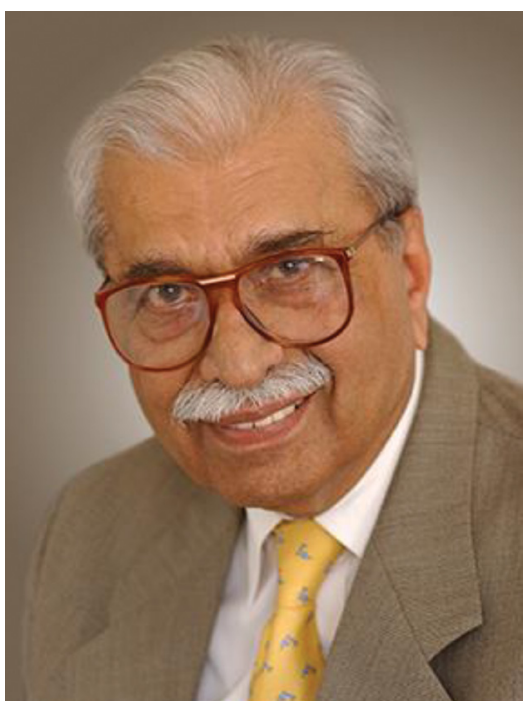

(Extracted from Google Images: www.worldneurologyonline.com, October 9th, 2016). Figure 1. Noshir Hormusji Wadia (1925-2016).

\footnotetext{
¿Universidade Federal do Paraná, Hospital de Clínicas, Departamento de Medicina Interna, Unidade de Distúrbios do Movimento, Serviço de Neurologia, Curitiba PR, Brasil;

${ }^{2}$ Universidade Federal de São Paulo, Divisão de Neurologia Geral e Unidade de Ataxia, Departamento de Neurologia, São Paulo SP, Brasil.

Correspondence: Hélio A. G. Teive; Rua General Carneiro, 1103/102; 80060-150 Curitiba PR, Brasil; E-mail: hagteive@mps.com.br

Conflict of interest: There is no conflict of interest to declare.

Received 13 November 2016; Accepted 06 December 2016.
} 
of the American Neurological Association, fellowship of the Indian National Science Academy, the SS Bhatnagar Indian National Science Academy medal for Excellence in General Science, as well as various other honors ${ }^{5}$. Wadia was also involved with the Sree Chitra Tirunal Institute of Medical Sciences and Technology, of which he was president. He was president of the Neurological Society of India (1963-1964) and a Fellow of the National Academy of Sciences, India, the Indian Academy of Sciences and the Indian National Science Academy $^{5}$. He undertook many activities with the World Federation of Neurology and was awarded the their medal for Services to International Neurology in 2009. Prof. Wadia died on April 10 ${ }^{\text {th }}, 2016$, at the age of $91^{5}$.

\section{WADIA'S CONTRIBUTIONS TO NEUROLOGY}

Wadia made countless contributions to neurology, some of the most notable being studies on manganese poisoning, tuberculous spinal meningitis, congenital atlanto-axial dislocation with myelopathy, and Wilson's disease in the Parsi community ${ }^{5}$. He published over 130 papers, several chapters in important books and a famous book Neurological Practice: an Indian Perspective 5 . One of Wadia's best-known contributions was the identification of an adult polio-like disease associated with a hemorrhagic conjunctivitis later known as enterovirus 70 disease ${ }^{5}$. Among his many contributions to neurology and, in particular, to the development of a neurology focusing on the needs of India, we concentrate here on his invaluable work in the field of spinocerebellar ataxias ${ }^{5}$. This work was carried out at a time when not only had the advanced genetics techniques available to us today not been developed, but also there was not even an adequate system for classifying the various entities that were being discovered. The most important contribution by Prof. Wadia was the identification, for the first time, of spinocerebellar ataxia with slow eye movements, nowadays defined as SCA $2^{4-7}$.

\section{SPINOCEREBELLAR ATAXIA TYPE 2 - WADIA'S SEMINAL STUDY}

In 1971, Wadia published the article $A$ new form of heredo-familial spinocerebellar degeneration with slow eye movements (Figure 2), in which he describes his findings in sixteen patients from nine Indian families ${ }^{4}$. These patients presented with a form of cerebellar ataxia with slow saccadic eye movements ${ }^{4}$. Wadia noted that the disease had a clear autosomal dominant pattern in the affected families, with anticipation of age at onset between generations, and that the patients presented with hyporeflexia and features suggestive of peripheral neuropathy. The presence of cerebellar atrophy was suggested but not confirmed because a pathological study was not carried out and the only imaging examination available at the time was pneumoencephalography ${ }^{4}$. His interest in the disease, which was later called SCA 2, led to the publication, in 1975, of a model of an ocular subsystem based on his findings in these same patients $^{6,7}$. In the following years he was able to establish a correlation between clinical findings up to that time and olivopontocerebellar atrophy ${ }^{7}$. In the subsequent decade he made two important contributions to our understanding of SCA 2: he showed the importance of correct characterization of patterns of eye movement abnormalities when there is a suspected clinical diagnosis of SCA $2^{8}$, and he made progress in the field of genetics by suggesting that the populations affected by SCA 2 in Cuba, England, Japan and India had a common ancestor ${ }^{9}$. In 2008, his last publications on the subject paved the way for further research into the control of eye movements ${ }^{9,10}$. Based on histopathological assessment, he suggested that reduced saccade velocity in SCA 2 patients is a result of neuronal loss and reduced synaptic density of excitatory burst neurons in the caudal pons ${ }^{10}$. Pathological findings also enabled him to establish that the floccular and nodular pathways, which control smooth pursuit and vestibular reflexes, are relatively spared whereas elements of the dorsal vermis pathway controlling saccade adaptation are more involved ${ }^{10}$.

In conclusion, Prof. Wadia published several important studies in neurology, most notably the first description of SCA 2, which included a complete clinical evaluation and neuropathological study of the condition.

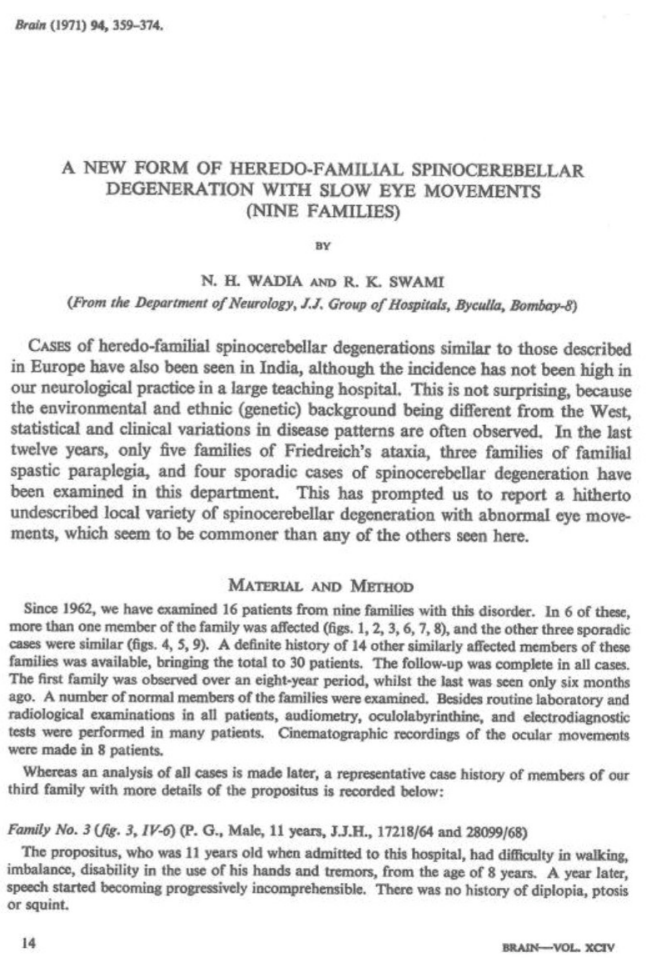

Figure 2. Front page of Wadia and Swami ${ }^{11}$. 


\section{References}

1. Pulst SM. Degenerative ataxias, from genes to therapies. The 2015 Cotzias Lecture. Neurology. 2016;86(24):2284-90. https://doi.org/10.1212/WNL.0000000000002777

2. Pedroso JL, Braga-Neto P, Escorcio-Bezerra ML, Abrahão A, Albuquerque MV, Rezende Filho FM et al. Non-motor and extracerebellar features in spinocerebellar ataxia type 2. Cerebellum. 2016 Jan 29. [Epub ahead of print]. https://doi.org/10.1007/s12311-016-0761-5

3. Orozco G, Estrada R, Perry TL, Araña J, Fernandez R, Gonzalez-Quevedo A et al. Dominantly inherited olivopontocerebellar atrophy from eastern Cuba: clinical, neuropathological, and biochemical findings.J Neurol Sci. 1989;93(1):37-50. https://doi.org/10.1016/0022-510X(89)90159-7

4. Wadia NH, Swami RK. A new form of heredo-familial spinocerebellar degeneration with slow eye movements (nine families). Brain. 1971;94(2):359-74. https://doi.org/10.1093/brain/94.2.359

5. Katrak SM, Singhal BS. Noshir Hormusji Wadia, MD, FRCP, FNA, FANA (1925-2016). Neurology. 2016;87(7):654-5. https://doi.org/10.1212/WNL.0000000000002995

6. Wadia NH. Heredo: familial spinocerebellar degeneration with slow eye movements: another variety of olivopontocerebellar degeneration. Neurol India. 1977;25(3):147-60.
7. Wadia N, Pang J, Desai J, Mankodi A, Desai M, Chamberlain S. A clinicogenetic analysis of six Indian spinocerebellar ataxia (SCA2) pedigrees. The significance of slow saccades in diagnosis. Brain. 1998;121(12):2341-55. https://doi.org/10.1093/brain/121.12.2341

8. Pang J, Allotey R, Wadia N, Sasaki H, Bindoff L, Chamberlain S. A common disease haplotype segregating in spinocerebellar ataxia 2 (SCA2) pedigrees of diverse ethnic origin. Eur J Hum Genet. 1999;7(7):841-5. https://doi.org/10.1038/sj.ejhg.5200372

9. Geiner S, Horn AK, Wadia NH, Sakai H, Büttner-Ennever JA. The neuroanatomical basis of slow saccades in spinocerebellar ataxia type 2 (Wadia-subtype). Prog Brain Res. 2008;171:571-81. https://doi.org/10.1016/S0079-6123(08)00683-3

10. Ying, SH, Horn AKE, Geiner S, Wadia NH, Büttner-Ennever JA. Selective, circuit-wide sparing of floccular connections in hereditary olivopontine cerebellar atrophy with slow saccades. Prog Brain Res. 2008;171:583-6. https://doi.org/10.1016/S0079-6123(08)00684-5

11. Wadia NH, Swami RK. A new form of heredo-familial spinocerebellar degeneration with slow eye movements (nine families). Brain. 1971;94:359-74. https://doi.org/10.1093/brain/94.2.359 